\title{
Employment-Oriented Public English Teaching Reform in Higher Vocational Colleges
}

\author{
Liu Siyang \\ Foreign Language Department \\ Jilin Institute of Chemical Technology \\ Jilin, China
}

\begin{abstract}
Higher vocational education carries the responsibility of educating higher-quality, high-skilled social application talents, which is the driving source behind enterprise development. However, at present, Chinese higher vocational students' comprehensive quality and the resultantly employment quality are not high, which is not conducive to the service function of higher vocational talents to social production. Among the qualities that vocational students lack, the insufficiency of English application ability is one of the unfavorable factors. Therefore, it's necessary to carry out employment-oriented public English teaching. This paper analyzes various demand of the employment, the combing English teaching with the major and the post ability that the English teaching faces in higher vocational colleges, and puts forward some suggestions on the reform of employment-oriented teaching from the aspects of clarifying teaching objectives, introducing new teaching modes, enriching teaching contents, school-enterprise cooperation and the construction of faculty team, which will improve the effectiveness of English teaching in higher vocational colleges and ultimately realize the teaching goal of training talents who can truly meet the needs of professional positions and social development in the future.
\end{abstract}

Keywords -employment-oriented; higher vocational college; public English; teaching reform

\section{INTRODUCTION}

Higher vocational education, as an important part of China's education system and also the focus of the county's education and social education, carries the responsibility of educating higher-quality, high-skilled social application talents, which is an indispensable source of productivity and the driving source behind enterprise development. However, at present, some abilities of higher vocational students are not high, which affects the comprehensive quality and results in poor employment quality, and is not conducive to the service function of higher vocational talents to social production. Among the qualities that vocational students lack, the insufficiency of English application ability is one of the unfavorable factors. It is imperative to carry out English course reform, which aims to determine the direction of English quality training, improve the English ability of vocational students, explore teaching methods, and innovate

Jilin Provincial Department of Education 2017 Vocational Education and Adult Education Teaching Reform Research Project "Employment-Oriented Higher Vocational English Curriculum Reform Research and Practice" (Project No. 2017ZCY323) teaching models.

\section{THE NECESSITY OF EMPLOYMENT-ORIENTED PUBLIC ENGLISH TEACHING REFORM IN HIGHER VOCATIONAL EDUCATION}

With the development of society and the diversification of occupations, higher vocational and technical education has a strong development momentum in China. The objective of higher vocational education is to train qualified application talents suitable for production, construction, management and service on the front line for national and local economic development. [1] It can be said that higher vocational education is "social demand-oriented employment education". [2]

With the globalization of economic development, English, as the universal language of communication among countries, has become a major manifestation of the basic quality in the career development of contemporary college students. According to the survey, enterprises and units are in urgent need of comprehensive talents who have both good professional knowledge and certain foreign language communication abilities. [3] As far as the current employment situation in China is concerned, if higher vocational students have excellent vocational skills, a good professional support and English application ability, it will be more conducive to their employment. Therefore, higher vocational English plays an important role in the whole vocational curriculum system. The quality of higher vocational English teaching and the level of students' English application ability are related to the improvement of the overall level of higher education in China and the improvement of employment rate of higher vocational graduates.

\section{THE DEMAND OF EMPLOYMENT-ORIENTED TEACHING FOR HIGHER VOCATIONAL ENGLISH COURSES}

Employment orientation requires the content of public English teaching in higher vocational colleges to meet the professional needs closely, so that the students can have a good professional practical English ability, which can be used by the students in the actual posts. Employment-oriented teaching has the following requirements for English courses: 


\section{A. The Demand of Employment}

Employment demand is one of the important goals of vocational English teaching. In the employment-oriented English teaching in higher vocational colleges, both students' emotional needs and cognitive needs should be paid attention to, so as to form their language competence and meet their development needs. As far as subject teaching is concerned, employment demand is the basic requirement of comprehensive language application ability, which is reflected in language skills and knowledge, emotional attitude, learning strategies and other aspects. Therefore, the employment needs should be fully considered when we set teaching goals.

\section{B. The Need of Combing English Teaching with the Major}

The combination with the major is another important goal of higher vocational English teaching. The employmentoriented English teaching in higher vocational colleges is to closely combine the teaching content with the specialty, so as to achieve the training goal of being application-oriented and adequate. We should focus on professional content and English expression as a supplement, use various appropriate teaching methods and teaching methods and colorful practical training activities to cultivate students' practical English application ability and expression ability. We should focus on professional content and English expression as a supplement, use various appropriate teaching methods and teaching methods and colorful practical training activities to cultivate students' practical English application ability and expression ability [4].

Higher vocational English teaching can be divided into teaching English for general purpose (EGP) and teaching English for special purpose (ESP). The former belongs to the basic competence category and the latter belongs to the professional competence category. ESP courses are in line with the demand of higher vocational colleges for talent training. Higher vocational education trains practical and skilled talents, and its core is the cultivation of ability. For example, international trade majors can offer courses of ecommerce English and foreign trade English, teaching the students to write various foreign trade letters and telegrams, customs declarations, invoices and bills of lading. Computer majors can set up computer English course, asking the students to collect related software and hardware specifications. Accounting majors can learn and prepare various English accounting statements. Only by combing professional English teaching content with students' professional knowledge, combing classroom teaching with social practice can students' special English application ability be better cultivated.

\section{The Requirement of Post Ability}

Post ability is the core goal of vocational English teaching. It includes the ability to communicate in the language, the ability to read medium difficulty English materials, the ability to write common application texts, and the ability to learn English sustainably.

First, since a large number of higher vocational students are required to work in English in their future jobs, if the students do not have a certain level of English, they will not be qualified for the job. Therefore, based on the requirements of the workplace, students should be cultivated to have the ability to communicate in daily and foreign-related business activities, the ability to communicate in English in a certain working environment and the communication skills needed in the workplace.

Second, according to the requirements of the syllabus of higher vocational education, we should train students to read brief English materials on general subjects of moderate difficulty, especially the ability of general short and practical writing materials, such as letters, product descriptions, technical specifications, contracts, etc. especially the ability of general short and practical writing materials, such as letter, product description, technical specification, contract, etc. At the same time, in the cultivation of reading ability, more English applicable articles related to this major will be introduced to enable students to have the ability to read general materials and practical articles related to the industry with the help of reference books, so that English can truly serve the profession.

Third, in the vocational English teaching, students should be trained to write the common application materials needed for professional posts. Students should be able to write English resume, product introductions, notice, invitation letters, product specifications, technical guidance, maintenance guide, etc.

Fourth, jobs require that employers not only have high vocational skills, but more importantly, they must have the ability to adapt, survive and develop, and the skills they can use what they have learned throughout their lives. It is impossible for a teacher to teach students the knowledge he or she has used all his or her life in the short college time. Only by mastering the methods and skills of English learning, can one gain lifelong benefits. This kind of education is called lifelong education. It requires learners to have independent thinking and self-management ability, master the methods needed to learn new knowledge, understand the strategies to solve difficulties encountered, and be able to choose the correct way of handling according to specific learning tasks. It can be seen that the mastery of methods and strategies is more important than the learning of knowledge.

\section{SUGGESTIONS FOR EMPLOYMENT-ORIENTED ENGLISH TEACHING REFORM}

The reform of English teaching in vocational education must take foreign language competence as the core, workplace background as the basis, and practical training as the way to improve the ability of foreign language communication in the workplace environment. There are some suggestions for employment-oriented English teaching reform in higher vocational colleges to cultivate students' English application ability and humanistic quality.

\section{A. Clarifying the Teaching Objectives of Combining English Ability with Humanistic Quality}

As a language, English is both instrumental and cultural. Currently, college English courses in higher vocational 
colleges are public courses offered to all non-English majors, covering all majors and classes. In order to cultivate students' professional English ability and humanistic quality, the vocational English course should highlight this teaching objective clearly. At the beginning of the class and throughout the teaching process, teachers should always emphasize this teaching goal to students and change students' concept of learning English only for examination. At the same time, the teaching design of vocational English courses in higher vocational colleges should give consideration to both instrumental and humanistic features, emphasize the communicative nature of culture, focus on the interaction of language and cognition, motivate students' enthusiasm and motivation, shape their personality, and cultivate students' good habits, character and emotions.

\section{B. Introducing Project-Based Teaching Mode}

Modern vocational education as a type of education, its development goal is employment-oriented. Therefore, the course content taught in vocational education should be connected with the professional standards, and the teaching process should be aligned with the production process. The traditional teaching mode of higher vocational English classroom can not achieve the goal of modern vocational education, and it is necessary to introduce a project-based teaching mode [5].

Project-based teaching method refers to that students handle a project in person under the guidance of teachers. The main theoretical basis of project-based teaching method is constructivist learning theory, Dewey's pragmatic education theory and situational leaning theory. By introducing the project-oriented teaching mode to vocational English classes, taking the real English communication task of working situation as the main line, integrating the teaching content and guiding students to complete the set projects, the integration of "teaching, learning and doing” can be realized.

Throughout the teaching process, the teacher is the mentor, and the student is the executive who completes the project. Teachers should integrate multiple teaching methods such as situational teaching method, case teaching method, communicative interactive teaching method and group cooperative teaching method. At the same time, with the help of multimedia equipment and Internet-assisted teaching, the aim of "everyone can learn everywhere and anytime" can be realized. The project-based teaching model emphasizes students' independent learning, active participation, creativity and initiative, so it can better cultivate students' English application ability and effectively connect with the workplace.

\section{Adding Professional English Learning Content}

At present, several publishing institutions, such as the Foreign Language Teaching and Research Press, have issued vocational English teaching materials, which are aimed at different industries. It is very helpful for students to master their professional English and is conducive to the connection with the industry. Professional English learning content should be added in the second academic year for qualified higher vocational colleges, so that students can further carry out professional and targeted vocational English learning after completing the basic English learning in the first academic year, so as to meet the higher requirements of employers on professional aspects. As for whether the professional English should be taught by the public English teachers or the professional teachers of each department, we can try the cooperative teaching mode between the public English teachers and the professional teachers with certain English foundation. Public English teachers have more advantages in oral English, vocabulary, grammar knowledge and teaching methods, while professional teachers have advantages in professional theory, practice and terminology. Both sides can learn from each other in cooperation, which helps to cultivate students' professional English ability. [6]

\section{Pushing School-Enterprise Cooperation}

The improvement of vocational college students' English ability needs to be supported by school-enterprise cooperation. Employment-oriented English training must be guided and deeply involved by enterprises. Higher vocational colleges should cooperate with enterprises to integrate education with enterprise atmosphere and enterprise culture. Through exploring and establishing a long-term mechanism, setting up the experimental practice base in the college, and constantly updating cooperation relationship between enterprises and colleges, we can expand the ways for the cultivation of the English level of the students with their English skills, improve students' practical English skills for professional posts in enterprises, achieve a smooth transition from the college to the enterprise work.

Currently, some higher vocational colleges have experimental training bases, but they are only used in the construction of professional teaching, rather than playing their due role in the cultivation of students' English quality, and fail to take into account the improvement of students' comprehensive quality. Through the teaching reform, the experimental training base in the specialty construction can be fully utilized. Through the cooperation between colleges and enterprises, higher vocational colleges can grasp the enterprises' current demand for talents, so we can carry out professional construction, curriculum system construction, update teaching content, transform and adjust teaching mode in accordance with the certain target, which will avoid the students' difficult transition to posts and ultimately benefit the enterprise by directly recruiting skilled talents. If necessary, the English curriculum of higher vocational colleges can also be changed according to the needs of enterprises, and the English teaching courses can be added or adjusted. Cooperation will not only cultivate the needed talents, but also create a "learning enterprise" environment for the enterprise.

\section{E. Strengthening the Construction of the Faculty Team}

As the designer and organizer of the teaching activities, the teacher is the key to achieve the teaching goals. In the context of employment orientation, in addition to the improvement of English vocational skills, English teachers in higher vocational colleges should actively participate in social work practice and strive for the transformation of "double-qualified" teachers. Teachers should combine English teaching with students' major, English ability and employment demand to form 
characteristic vocational teaching. Besides, colleges should create opportunities for English teachers to visit and practice in enterprises regularly so that they can constantly improve their practical teaching ability. In enterprises, teachers can also obtain first-hand market information which can bring students new knowledge and new technology on the front line of production and management.

\section{CONCLUSION}

In the first "vocational education activity week", Premier Li Keqiang particularly emphasized vocational education which could cultivate a high-quality workforce and improve the level of Chinese manufacturing and service. Public English as the basic course in the vocational education system, the ultimate goal of the employment-oriented teaching reform is to improve the students' comprehensive English quality, professional English quality and practical English quality, so that they can make full use of time in school to realize gaining from learning, which will eventually shorten the distance between school education and demand of the enterprise and the goal that the school provides high-quality talents for the enterprise is achieved. Therefore, higher vocational colleges should set and adjust courses according to the actual needs of social development and employment, so as to improve the effectiveness of teaching and cultivate talents who can truly meet the needs of future career and social development.

\section{ACKNOWLEDGMENT}

The study is supported by The Research Center for Foreign Language Education in Engineering Institutes of Jilin Province, The Key Research Base of Humanities and Social Science of Jilin Province.

\section{REFERENCES}

[1] Department of Higher Education, Ministry of Education of the People's Republic of China. "The basic requirements of English teaching in higher vocational colleges"(in Chinese), M. Beijing: Higher Education Press, 2006

[2] Zhou Ji, "Command the overall situation of education with scientific outlook on development--speech at the 2005 annual working conference of the Ministry of Education” (in Chinese), Z. Bulletin of the Ministry of Education of People's Republic of China.

[3] Yi Heng, "Employment-oriented reform of public English teaching in higher vocational college"(in Chinese), J. Journal of Suzhou Education Institute. Apr. 2017, vol. 20, pp. 108-109-74.

[4] Chen Xiuli, "Employment-oriented teaching reform of English in higher vocational colleges"(in Chinese), J. Education and Vocation, Feb. 2012, vol. 718, pp. 137-138.

[5] Ju Lili, "Employment-Oriented vocational English Practical Ability and Humanistic Quality Training”(in Chinese), J. English Square, Nov. 2015, vol.059, pp. 109-110.

[6] Zhu Dandan, Ma Jinsong, "Employment-oriented reform and innovation of public English curriculum in higher vocational colleges”(in Chinese), J. Journal of Hubei University of Economics (Humanities and Social Sciences), Feb. 2014, vol.11, pp.214-215. 